\title{
Tejsav oligomerrel lágyított, politejsav-alapú biopolimer habok előállítása
}

\section{Production of Biopolymer Foams Based on Polylactic Acid Plasticized With Lactic Acid Oligomer}

\author{
Litauszki Katalin, ${ }^{1}$ Kmetty Ákos ${ }^{1,2}$ \\ ${ }^{1}$ Budapesti Müszaki és Gazdaságtudományi Egyetem, Gépészmérnöki Kar, Polimertechnika Tanszék. \\ Budapest, Magyarország, litauszkik@pt.bme.hu \\ ${ }^{2}$ MTA-BME Kompozittechnológiai Kutatócsoport.Budapest, Magyarország, kmetty@pt.bme.hu
}

\begin{abstract}
In our work, we modified polylactic acid biopolymer using oligomeric lactic acid. We have successfully plasticised polylactic acid compounds with 5, 10, $20 \mathrm{wt} \%$ oligomeric lactic acid using a liquid dosing system connected to a compounder extruder. The produced compounds were foamed with an exothermic chemical foaming agent. The density of the foams was measured and the fracture surfaces were examined by electron microscopy to assess the homogeneity of the cell structure. Based on this, we believe that the plasticising effect of oligomeric lactic acid is undeniable, but a processing temperature of $190{ }^{\circ} \mathrm{C}$ is not optimal for the foaming process. In the future, the production of biopolymer foam structures with a higher density reduction can be achieved by reducing and optimizing the foam processing temperature.
\end{abstract}

Keywords: poly lactic acid, plasticised, extrusion, foam.

\section{Összefoglalás}

Munkánk során a politejsav biopolimer alapvetően rideg viselkedését módosítottuk oligomer tejsav alkalmazásával. Sikeresen állítottunk elő folyadékadagoló használatával 5, 10, 20 \%-ban oligomer tejsavval lágyított politejsav-keverékeket ikercsigás extrudálás segítségével. A gyártott keverékeket exoterm kémiai habképzővel habosítottuk. Az ilyen módon képzett habok sűrűségét mértük, illetve a töretfelületeket elektronmikroszkóppal vizsgáltuk, hogy a cellaszerkezet homogenitását, valamint a cellapopuláció-sűrűséget értékelhessük. Mindezek alapján úgy véljük, hogy az oligomer tejsavval való lágyítás hatékonysága tagadhatatlan, viszont a $190{ }^{\circ} \mathrm{C}$-os gyártási hőmérséklet nem ideális a habképzés szempontjából. A jövőben a gyártási hőmérséklet csökkentése és optimalizálása esetén a kedvezőbb sűrűségű biopolimer habok gyártása ígéretes továbblépést jelenthet.

Kulcsszavak: politejsav, lágyító, extrúzió, hab.

\section{Bevezetés}

Napjainkban igen fontos szerepet töltenek be a polimerek. A gyártott polimer alapanyagok mennyisége 2019-ben 368 millió tonna volt [1]. A nagymértékű polimerfelhasználás, amelynek közel 40\%-a csomagolási célú, komoly hulladékgazdálkodási kérdéseket vet fel. A biopolimerek csoportja ígéretes polimer alapanyag lehetősé- gét nyújtja a környezetterhelés szempontjából. A biopolimerek éves szinten megújuló erőforrásból, biológiai úton előállítható polimerek, mindemellett biológiai úton lebonthatók. E kedvező tulajdonságaik miatt a kutatások középpontjában állnak mint ígéretes alternatívái a kőolajalapú polimereknek, kifejezetten a rövid életciklusú termékek kapcsán. A politejsav (PLA) az egyik 
legígéretesebb biopolimer alapanyag, és mivel nagy mennyiségben állítják elő (140 000 tonna/ év), ezáltal a többi biopolimerhez mérten relatíve olcsó ( $2 \$ / \mathrm{kg}$ ) [2], amellett, hogy a jelenlegi feldolgozóberendezésekkel feldolgozható. A politejsav alkalmazhatóságának kibővítéséhez, annak hátrányos tulajdonságain módosítani szükséges. A PLA egyik legnagyobb hátránya a ridegsége és a kis nyúlása. E tulajdonságok javítására alkalmas módszer a PLA belső vagy külső lágyítása. Ebben az esetben polimerizáció után kémiai reakció lezajlása nélkül, belső lágyítóként módosítjuk a polimer tulajdonságait. Az ilyen módon lágyított rendszerben nem a polimerlánc megváltozása, hanem a láncok közé beépülő lágyítómolekulák lépnek kölcsönhatásba a polimer molekuláival, ezzel megváltoztatva annak tulajdonságait [3]. A PLA lágyítása kapcsán többféle lágyítószerrel is kísérleteztek, így például vizsgálták különböző molekulatömegű polietilénglikol $[4,5]$ és citrátészter lágyító hatását is [5]. Az egyik legígéretesebb lágyítószer maga a politejsav oligomer változata. Az oligomer tejsavat (OLA) és a PLA-t felépítő ismétlődő egység felépítése azonos, különbség csupán az ismétlődő egység számában van, azaz a molekulatömegében. Míg egy átlagos polimert százezer nagyságrendű ismétlődő egység épít fel, addig oligomerek esetében csupán pár ezer, így molekulatömegük is nagyságrendekkel kisebb.

A politejsav-alapú habok gyártása, a gyártott habok ridegségének csökkentése és energiaelnyelő képességének növelése jelenleg is aktívan kutatott terület. A habképzés tekintetében a kevéssé kutatott, kémiai típusú habképzést jellemzően exoterm típusú habképzőszerrel valósítják meg [6]. A legelterjedtebb exoterm habképzőszer az azodikarbonamid [6]. A kémiai habképzés egyik előnye, hogy a megvalósításához nem feltétlenül szükséges a feldolgozó extrudert módosítani. A habok ridegségének csökkentésére alkalmas lehet a politejsav oligomer tejsavval történő blendképzése, így kiemelt érdeklődésre tarthat számot az ilyen módon létrehozott blendek habosítása.

\section{A felhasznált alapanyagok, az anyagvizs- gálatok és gyártástechnológia ismerte- tése}

A kísérlethez a NatureWorks LLC Ingeo 4032D típusú biopolimerét választottuk, amely extrudáláshoz javasolt politejsav. D-laktid-tartalma 1,4\%, ezáltal kristályosodásra hajlamos polimer [7]. Sürüsége $1,24 \mathrm{~g} / \mathrm{cm}^{3}$ [8]. A felhasznált tejsav oligomer a Condensia cég által gyártott Glyplast OLA 2 volt. Észtertartalma $>99 \%$. Sürűsége
$1,10 \mathrm{~g} / \mathrm{cm}^{3}$. Viszkozitása $40{ }^{\circ} \mathrm{C}$-on $90 \mathrm{mPa} \cdot \mathrm{s}$. A választott OLA-típust 5, 10 és 20\%-ban adagoltuk a PLA-hoz. A felhasznált habképzőszer a Tramaco GmbH cég által gyártott Tracel IM 3170 MS volt, granulátum formában. E habképzőszer azodikarbonamidot (ADCA) tartalmazó, exoterm kémiai típusú habképzőszer. Termikus bomlása $147-212{ }^{\circ} \mathrm{C}$ közé tehető [9].

A keverékképzéshez Labtech LTE 26-44 típusú, ikercsigás extrudert használtunk, Labtech IZ-120/ VS folyadékadagolóval kiegészítve, amelynek használatával a $70{ }^{\circ} \mathrm{C}$-ra előmelegített OLA-t közvetlenül az ömledékbe juttattuk. Az OLA-t az ikercsigás extruder 3. zónájában injektáltuk a politejsav-ömledékbe, így elősegítve annak homogén keveredését. Az alkalmazott hőmérsékletprofil $180 / 185 / 185 / 190 / 190 / 190 / 195 / 195 / 200 / 200 / 200{ }^{\circ} \mathrm{C}$ volt. Az extrudercsiga fordulatszáma 25 fordulat/ perc, az adagoló fordulatszáma 8,5 fordulat/perc. Az extruderrel készített zsinór előgyártmányból Labtech LZ-120/VS típusú granulálóval granulátumot készítettünk, amelyet így a későbbi habosítás alapanyagaként használtunk fel. A PLA-alapanyagot minden esetben a gyártás előtt $80^{\circ} \mathrm{C}$-on, 6 órán keresztül szárítottuk WGL-45B (Huanghua Faithful Instrument Co., Kína) típusú szárítóberendezés segítségével.

A habok előállításához Collin Teach-Line ZK25T típusú, ikercsigás extrudert alkalmaztunk árasztásos adagolással. A Tracel IM 3170 MS típusú kémiai habképzőszert (CBA) előzetes kísérleteink alapján [10], 2\%-ban a PLA-granulátumhoz kevertünk száraz keveréssel. Az alkalmazott hőmérsékletprofil $155 / 160 / 175 / 190 / 190{ }^{\circ} \mathrm{C}$ volt. Az extruder csiga fordulatszáma 10 1/min volt.

Differenciális pásztázó kalorimetriai (DSC) mérésekhez a TA Instruments Q2000 típusú, automata mintaváltós DSC-berendezését használtuk. A vizsgálati hőmérséklet-tartomány -20 és $200^{\circ} \mathrm{C}$ között volt, amelyet a szakirodalmi kutatás alapján várható üvegesedési átalakulási hőmérséklet alapján határoztunk meg. A fütés sebessége $5{ }^{\circ} \mathrm{C} / \mathrm{min}$ volt. A minta tömege 3-6 mg közötti. A vizsgálati közeg nitrogén.

Termogravimetriai analízishez (TGA) a TA Instruments Q500-as TGA készülékét használtuk, amelynek szintén van automata mintaváltója. A vizsgálat hőmérséklet-tartománya $50-600{ }^{\circ} \mathrm{C}$. A fütés sebessége $10^{\circ} \mathrm{C} / \mathrm{min}$ volt. A minta tömege 3-6 mg közötti. A vizsgálati közeg ipari tisztaságú levegő, $60 \mathrm{~mL} / \mathrm{min}$ térfogatárammal.

$\mathrm{Az}$ alapanyagok reológiai vizsgálatához a TA Instruments (USA) által gyártott, AR2000 típusú oszcillációs reométert használtuk. A mérést lap- 
lap típusú, acél mérőtárcsák között végeztük. A vizsgálati hőmérséklet $190{ }^{\circ} \mathrm{C}$ volt. A vizsgált frekvenciatartomány 1-100 Hz, az alkalmazott deformáció $10 \%$ volt. A próbatest $25 \mathrm{~mm}$ átmérőjü, 1-2 mm közé eső vastagságú korong volt.

A habok cellaszerkezetét pásztázó elektronmikroszkóppal (SEM) vizsgáltuk. A vizsgálandó töretfelületeket kriogén töréssel állítottuk elő. A SEM-felvételeket JEOL JSM 6380LA típusú pásztázó elektronmikroszkóppal készítettük, $10 \mathrm{kV}$ gyorsítófeszültség alkalmazásával. Az előkészített mintákat mélyhütésben aranyoztuk argon gázas öblítéssel.

A keverékek és habok sűrüségét $10 \mathrm{~mL}$-es, 0,1 mL-es osztású mérőhengerrel mértük, desztillált víz mérőközegben. A tömegméréshez használt mérleg típusa OHAUS Explorer, amelynek méréshatára $110 \mathrm{~g}$, mérési pontossága 0,1 mg.

A cellapopuláció-sűrüség $\left[N_{c}\left(\mathrm{db} / \mathrm{cm}^{3}\right)\right]$ számítását az (1) egyenlet alapján végeztük, ahol $n(\mathrm{db})$ a töretfelület mikroszkópi képén látható cellák száma, $M$ a nagyítás, $A\left(\mathrm{~cm}^{2}\right)$ pedig a töret keresztmetszete. $E R$ az expanziót jelöli [11]. ER a tömör polimer és a hab sürüségének hányadosaként számítható.

$$
N_{c}=\left(\frac{n \cdot M^{2}}{A}\right)^{\frac{3}{2}} \cdot E R
$$

\section{A keverékek minősítése}

A keverékek minősítéséhez többféle mérést végeztünk, hogy minősíthessük azok morfológiai, termikus és reológiai tulajdonságait. A gyártott keverékek morfológiáját DSC-vizsgálattal minősítettük, hogy a lágyítótartalom hatását vizsgálhassuk a politejsav üvegesedési átalakulási $\left(T_{g}\right)$, hidegkristályosodás $\left(\Delta H_{c c}\right)$ és olvadás $\left(T_{m}\right)$ csúcshőmérsékletére. Az 1. ábra a különböző mértékben OLA-val lágyított keverékek első felfütése során kapott DSC-görbéit mutatja. A lágyítók egyik könnyen észlelhető és számszerűsíthető tulajdonsága, hogy az üvegesedési átalakulási hőmérsékletet a kisebb hőmérsékletek felé tolják el. Jól látható tendencia, hogy az üvegesedési átalakulási hőmérséklet a kisebb hőmérsékletek felé tolódik, illetve a hidegkristályosodás csúcshőmérséklete és az olvadás csúcshőmérséklete is ezzel egyező tendenciát mutat. Ez az OLA-val történő lágyítás hatására is megfigyelhető, és a változás $20 \%$ OLA esetén a legnagyobb $\left(61{ }^{\circ} \mathrm{C}\right.$-ról $26^{\circ} \mathrm{C}$-ra $)$, ahogyan az várható.

5\% OLA adagolása esetén megfigyelhető, hogy az OLA-adagolás hatására még nem történik elto-

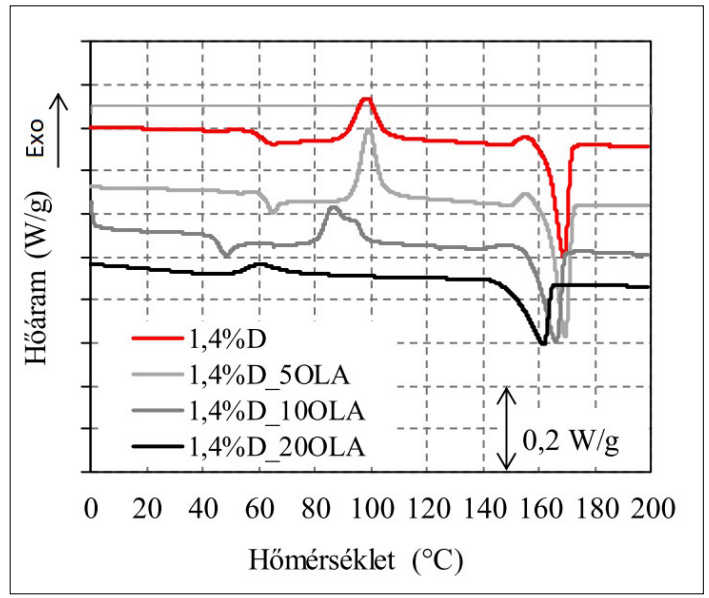

1. ábra. PLA és OLA-t tartalmazó keverékek höáramhömérséklet görbéi DSC-vizsgálat alapján

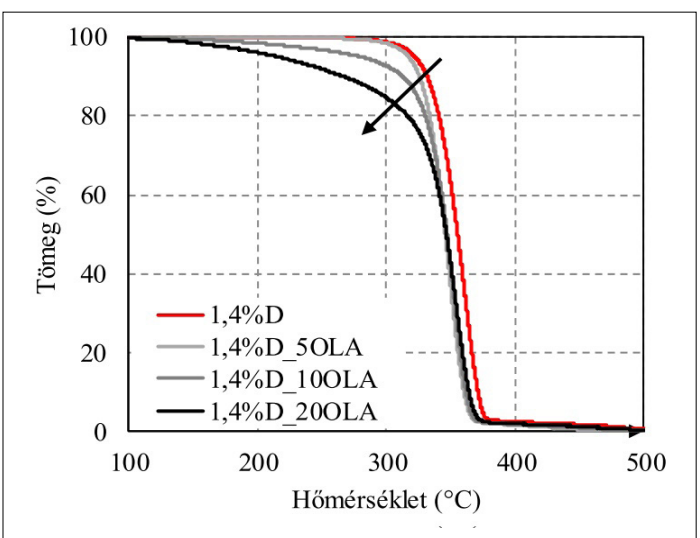

2. ábra. PLA és OLA-t tartalmazó keverékek tömegcsökkenésének mértéke a hömérséklet függvényében

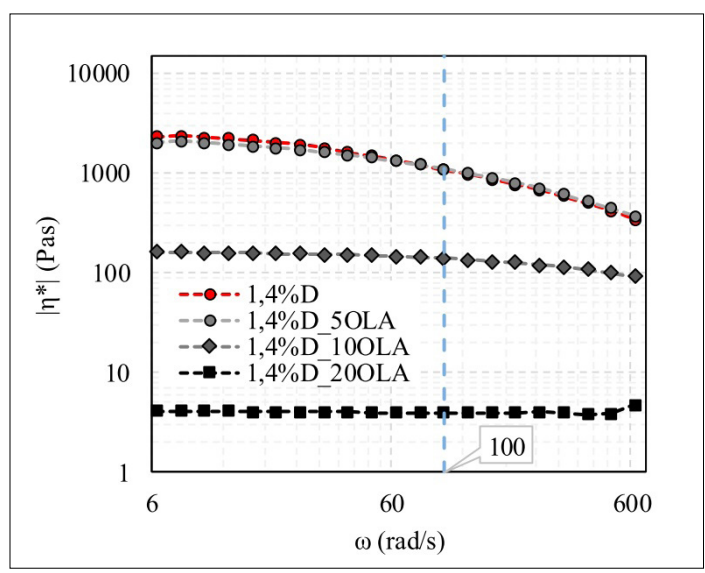

3. ábra. PLA és OLA-t tartalmazó keverékek komp-lex viszkozitásának abszolút értéke a szögsebesség függvényében 
lódás az üvegesedési átalakulási hőmérsékletben $\left(62^{\circ} \mathrm{C}\right)$. A szakirodalom eredményeivel összevetve sikerült kisebb $T_{g}$-t elérnünk, mint amiről Sinclair beszámolt [12], viszont nem sikerül elérnünk a Martin és Avérous által leírt, 37 és $18^{\circ} \mathrm{C}$-os üvegesedési átalakulási hőmérsékletet 10 , illetve $20 \%$ OLA adagolásával [13]. A Burgos és társai által 15\%-os OLA-adagolással elért, $36-40{ }^{\circ} \mathrm{C}$ közötti $T_{g}$ hőmérséklet körülbelül egybehangzó a mi mérési eredményeinkkel.

A PLA és PLA/OLA alapanyagból készült kompaundok TGA-görbéit a 2.ábra mutatja. Mivel kisebb molekulatömegü láncokat adtunk a PLA-mátrixhoz az oligomer tejsav formájában, a kezdeti, 5\%-os tömegvesztés esetén regisztrált hőmérséklet-csökkenés a vártnak megfelelő, hiszen ezek a kisebb molekulatömegü láncok mozgékonyabbak, és kisebb hőmérséklet hatására bomlanak. Fontos megjegyezni továbbá, hogy az 50\%-os tömegvesztéshez tartozó hőmérséklet csak kismértékben változott: ekkor a tömegcsökkenés lefutása közel azonos. Ez a tömegcsökkenési lépcső a PLA-hoz tartozik, és nem függ a lágyítótartalomtól.

Habképzés során kiemelt fontosságú a megfelelő ömledékszilárdság, mivel kis ömledékszilárdsággal a mátrix nem tudja a kialakuló cellákat megtartani, azok összeomlanak. Ezzel ellentétben a túlságosan nagy ömledékszilárdság esetén a létrejött cellagócok nem képesek megfelelő mértékben tágulni. Ezért vizsgáltuk a gyártott keverékek viszkozitását. A 3. ábra a PLA-ból készített keverékek komplex viszkozitásának abszolút értékét mutatja a szögsebesség függvényében. Kiemeltük a $100 \mathrm{rad} / \mathrm{s}$ szögsebességhez tartozó értékeket, mivel nagyságrendileg ezen érték feleltethető meg

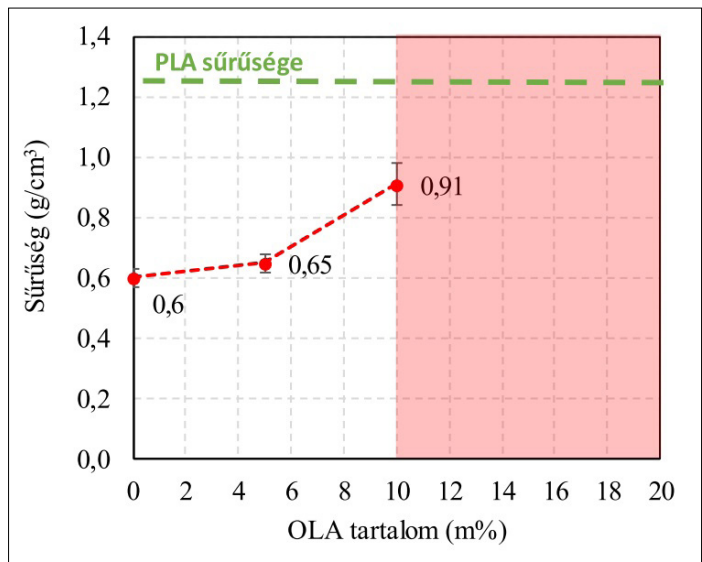

4. ábra. PLA-t és OLA-t tartalmazó habok sürüségeredményei az OLA-tartalom függvényében az extrúzió során fellépő nyírási sebességnek. Ez a $100 \mathrm{rad} / \mathrm{s}$ kisebb, mint egy átlagos extrúzióra jellemző nyírási sebesség, viszont a kis csigafordulatszám miatt ezzel közelíthetjük ebben az esetben. Megfigyelhető, hogy 5\% OLA adagolása nem befolyásolja jelentősen a minta viszkozitását, szemben a 10\%-os és 20\%-os keverékekkel, jelentős viszkozitáscsökkenést tapasztalunk.
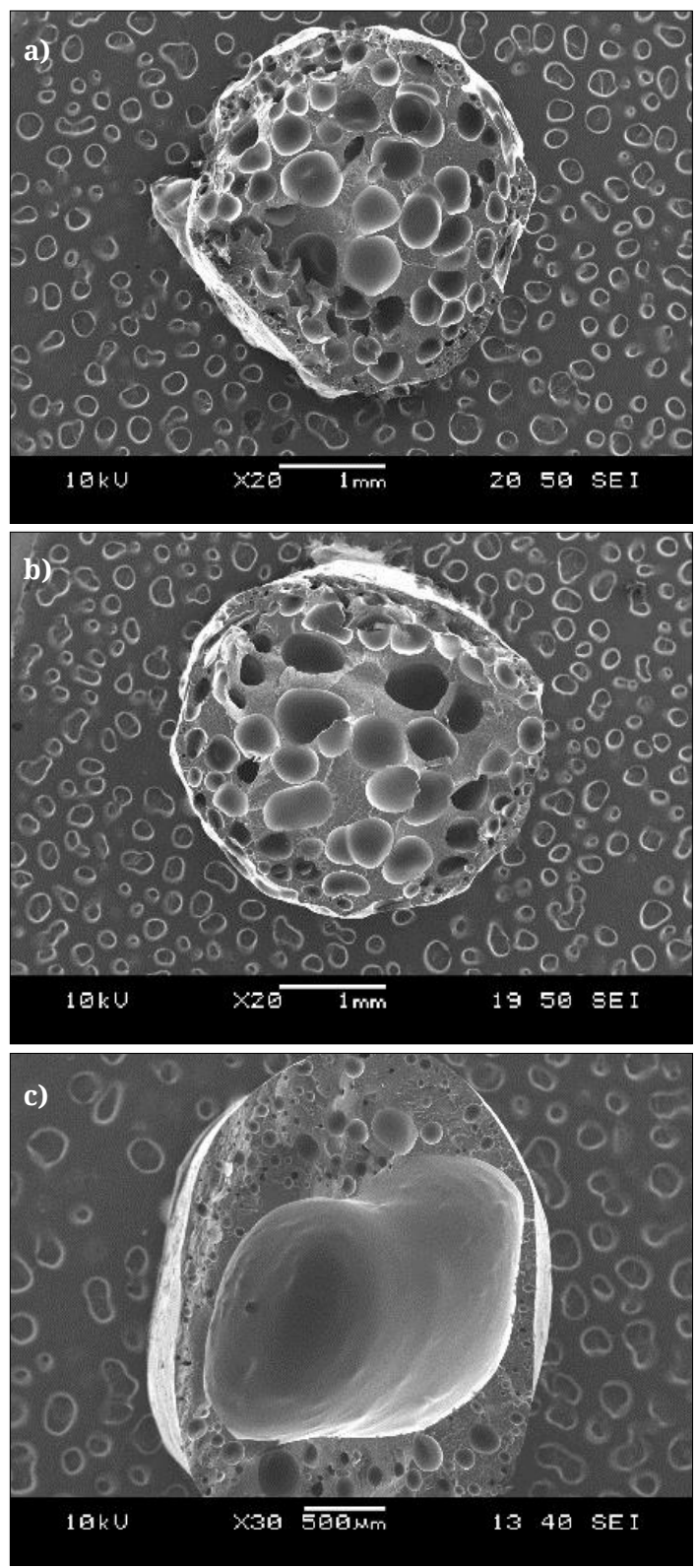

5. ábra. A habok elektronmikroszkópi felvételei fentről lefele haladva: a) 0, b) 5, c) 10\% OLA-tartalommal 


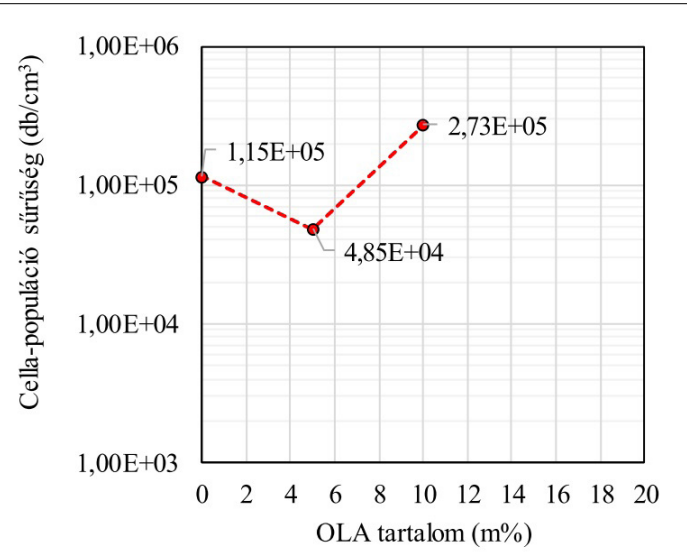

6. ábra. A habok cellapopuláció-sürüség értékei 0, 5, 10 m\% OLA-tartalom esetén

E görbék alapján arra következtethetünk, hogy a stabil habképzésre várhatóan az 5\% OLA-t tartalmazó keverék alkalmas, továbbá a 10\% OLA-t tartalmazó rendszerből kisebb hőmérsékleten, más habképző szerrel lehetséges lehet habot képezni.

\section{A habok szerkezetének vizsgálata}

A habképzés során referenciamintákat, illetve 2\%-ban CBA-val adagolt, PLA-alapú habokat gyártottunk ikercsigás extruderrel folyamatos üzemben. Elsőként a gyártott habok sűrüségét mértük. A sürüségmérés eredményeit a 4 . ábra mutatja. Egyértelmű tendencia, hogy a lágyítótartalom növelése a sűrűség növekedésével jár, aminek az oka az OLA viszkozitásra gyakorolt hatása. A kisebb ömledékszilárdságú mátrix nem képes a cellákat megtartani, így azok összeomlanak, összenőnek. A 20\% OLA-t tartalmazó keverék a gyártás során gyárthatatlannak bizonyult. Legkisebb sűrűséget a referenciaanyaggal, az OLA-t nem tartalmazó PLA-ból képzett habbal sikerült elérnünk $\left(0,6 \mathrm{~g} / \mathrm{cm}^{3}\right)$.

Az 5. ábra a habdarabokon mélyhütéssel/ cseppfolyós nitrogénben létrehozott töretfelületek elektronmikroszkópi felvételeit mutatja. Megfigyelhető a lágyítótartalom növelésének habok cellaszerkezetére gyakorolt hatása. A referenciahabhoz képest 5\% OLA hatására nem történt jelentős változás a cellaszerkezetben, viszont $10 \%$ lágyító hatására olyannyira lecsökkent a polimerömledék viszkozitása, hogy a cellák összeomlása a képen látható óriásbuborék kialakulásához vezetett, továbbá a gyártás sem volt folyamatos, mivel az ömledék nem tudta magában tartani a képződő habképző gázt. Megfigyelhető továbbá, hogy a hűtés hatására egy külső rétegben kisebb cellák képződtek, míg a minta belsejében nagyobb cellák tudtak kialakulni, mert a polimerömledék lassabban szilárdult meg, mint a külső részek.

Az elektronmikroszkópi felvételek alapján a cellák számából cellapopuláció-sűrűséget számítottunk. A 6. ábra az OLA-tartalom függvényében mutatja a cellapopuláció-sűrüséget. A legnagyobb cellapopuláció-sűrűséget a 10\% OLA-tartalmú minták mutatták, majd kicsit kisebbet a referenciahabok. A számított cellapopuláció-sűrüségek a Julien és társai által kémiai úton képzett habokhoz képest azonos, $10^{5}$ nagyságrendű cellapopuláció-sűrűséget értünk el [14]. Ez azonban önmagában nem minősíti a habot, ezt az elektronmikroszkópi felvételekkel együtt kell kezelni, hiszen a cellastruktúra méret- és eloszlásbeli homogenitásáról ez nem ad külön információt. Ebben az esetben ez különösen igaz lesz, hiszen $10 \%$ OLA adagolása esetén nagyon sok kis méretű cella képződött, viszont nem alakult ki homogén habstruktúra. Azonban 5\% OLA adagolása esetén a cellastruktúra kedvező, homogén jelleget mutat.

\section{Következtetések}

Sikeresen állítottunk elő folyadékadagoló alkalmazásával 5, 10, 20\%-ban OLA-val lágyított PLA-kompaundokat. A DSC-mérések segítségével rámutattunk az OLA üvegesedési átalakulási hőmérséklet-csökkentő hatására. A legnagyobb arányú $T_{g}$-csökkenést 20\%-os OLA-adagolás esetén értük el $\left(26^{\circ} \mathrm{C}\right)$. Ez összhangban van a szakirodalmi eredményekkel. Ez az eltolódás a $T_{c c}$ és $T_{m}$ esetében is megfigyelhető volt. Termogravimetriás analízissel a gyártott keverékek termikus stabilitását vizsgáltuk: az OLA hatására a kisebb hőmérsékletek irányába tolódtak el a bomlási hőmérsékletek. Reológiai méréseket végeztünk, hogy a különböző PLA/OLA receptúrák viszkozitását megismerjük, mivel ez szoros összefüggésben áll az adott keverék habosíthatóságával. A reológiai mérések és a későbbi habosíthatóság összhangban voltak egymással. A képzett hab sűrüségét mértük, illetve a töretfelületeket elektronmikroszkóppal vizsgáltuk, hogy a cellastruktúra homogenitását, valamint a cellapopuláció-sűrűséget értékelhessük. Mindezek alapján úgy véljük, hogy az OLA-val való lágyítás hatékonysága tagadhatatlan, viszont a $190{ }^{\circ} \mathrm{C}$-os gyártási hőmérséklet nem ideális a PLA/OLA keverék habképzése szempontjából. A jövőben a gyártási hőmérséklet csökkentése és optimalizálása kedvezőbb habsürüségű biopolimer habok gyártásának ígéretes lehetőségét jelentheti. 


\section{Köszönetnyilvánítás}

Ezúton szeretnénk köszönetet mondani a Tramaco GmbH-nak (Németország), illetve az INTERDIST Kft.nek a Tracel IM 3170 MS habképzőszermintáért, a Nemzeti Kutatási, Fejlesztési és Innovációs Hivatal K-132462 és NVKP_16-1-2016-0012. számú pályázatának, illetve a Bolyai János Kutatási Ösztöndíjért a Magyar Tudományos Akadémiának.

\section{Szakirodalmi hivatkozások}

[1] PlasticsEurope: Plastics - the facts 2019: An analysis of European plastics production, demand and waste data (2020).

[2] Plastics Insight: Polylactic Acid Properties, Production, Price, Market and Uses. (letöltve: 2020.12.12.) https://www.plasticsinsight.com/resin-intelligence/resin-prices/polylactic-acid/

[3] Edmund H. I., Herman F. M.: Principles of Plasticization In: Plasticization and Plasticizer Processes (eds.: Platzer N. A. J.) American Chemical Society, Philadelphia, USA, Vol 1, (1965).

[4] Pillin I., Montrelay N., Grohens Y.: Thermo-mechanical characterization of plasticized PLA: Is the miscibility the only significant factor? Polymer, 47/13. (2006) 4676-4682. https://doi.org/10.1016/j.polymer.2006.04.013

[5] Kulinski Z., Piorkowska E.: Crystallization, structure and properties of plasticized poly(l-lactide). Polymer, 46/23. (2005) 10290-10300. https://doi.org/10.1016/j.polymer.2005.07.101

[6] Lee S.-T., Park C. B.: Foam Extrusion: Principles and Practice. CRC Press, Boca Raton (2014).

[7] Kolstad J. J., Vink E. T. H., Wilde D. B., Debeer L.: Assessment of anaerobic degradation of Ingeo polylactides under accelerated landfill conditions.
Polymer Degradation and Stability, 97/7. (2012) 1131-1141.

https://doi.org/10.1016/j.polymdegradstab.2012.04.003

[8] Huang C., Thomas N. L.: Fabricating porous poly (lactic acid) fibres via electrospinning. European Polymer Journal, 99. (2018) 464-476.

https://doi.org/10.1016/j.eurpolymj.2017.12.025

[9] Kmetty Á., Litauszki K., Réti D.: Characterization of Different Chemical Blowing Agents and Their Applicability to Produce Poly(Lactic Acid) Foams by Extrusion. Applied Sciences, 8. (2018) 1-17. https://doi.org/10.3390/app8101960

[10] Litauszki K., Kmetty Á.: Characterization of chemically foamed poly(lactic acid). In: OATK. Balatonkenese, Materials Science and Engineering 903. (2020) 012018.

https://doi.org/10.1088/1757-899X/903/1/012018

[11] Xu X., Park C. B., Xu D., Pop-Iliev R.: Effects of die geometry on cell nucleation of PS foams blown with $\mathrm{CO}_{2}$. Polymer Engineering \& Science, 43/7. (2003) 1378-1390.

https://doi.org/10.1002/pen.10117

[12] Sinclair R. G.: The Case for Polylactic Acid as a Commodity Packaging Plastic. Journal of Macromolecular Science, Part A, 33. (1996) 585-597. https://doi.org/10.1080/10601329608010880

[13] Martin O., Avérous: L.: Poly(lactic acid): plasticization and properties of biodegradable multiphase systems. Polymer, 42/14. (2001) 6209-6219. https://doi.org/10.1016/S0032-3861(01)00086-6

[14] Julien J., Bénézet J., Lafranche E., Quantin J., Bergeret A., Lacrampe M., Krawczak P.: Development of poly(lactic acid) cellular materials: Physical and morphological characterizations. Polymer, 53/25. (2012) 5885-5895.

https://doi.org/10.1016/j.polymer.2012.10.005 